\title{
Tama-ki-Hikurangi: A whare built for Te Kooti
}

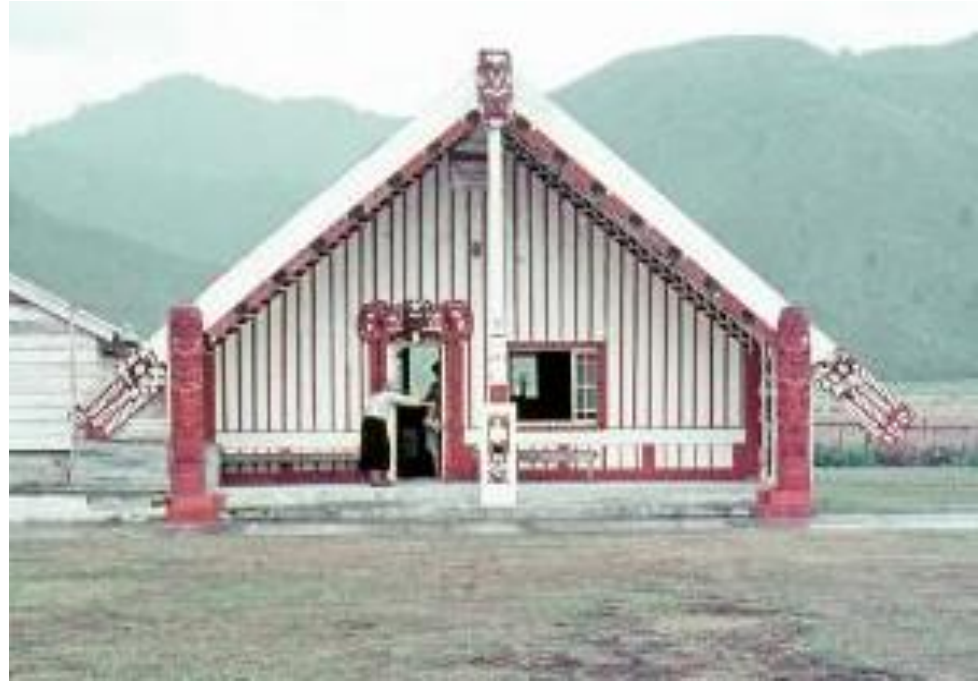

Figure 1. Tama-ki-Hikurangi (Mead, 1970, PID530310)

\section{Introduction}

For the followers of the famous nineteenth-century prophet Te Kooti in Waiōhau, Tama-ki-Hikurangi is an integral part of their whakapapa, history, and theology. Patuheuheu are followers of Te Kooti and as such, the Ringatū faith-the religion that he created-is part of 
what it means to be Patuheuheu. While adherence to the faith has waxed and waned, the whare, Tama-kiHikurangi remains as a focal point of Patuheuheu's historical connection to Te Kooti and the Ringatu faith. Indeed, the faithful still gathers in the whare most Saturdays to hold hāpati-sabbath-day prayers. Tamaki-Hikurangi was built for Te Kooti, and its size and design is a direct result of Te Kooti's syncretistic theology. This paper is an exploration of what is known about the whare from a Patuheuheu perspective.

\section{Patuheuheu}

The notion of "hereditary entanglement" recognises the "inseparability of genealogical locatedness" in Māori research (Rangiwai, 2018a, p. 139). Therefore, an explanation of the origins of Patuheuheu hapu, as a distinct identity, and my place within the whakapapa and history of Patuheuheu hapu is required to validate this paper.

Local oral history recollects when the Patuheuheu and Ngāti Haka identities were genealogically separate (Rangiwai, 2018b). Due to intermarriage and interdependence, the two hapu are often understood to be one identity (Rangiwai, 2018b). However, this paper is written from a Patuheuheu perspective and is therefore based in Patuheuheutanga.

Best (1925) asserts that Patuheuheu and Ngāti Haka originated from the Ngāti Rākei hapū, which had once lived at Ōhāua-te-rangi in the Ruatāhuna area, before moving to Horomanga, Te Houhi, Waiohau and other areas (Best, 1925). Best (1925) opines:

...Patu-heuheu are to a large extent Ngati-Rongo. These people lived at O-haua-te-rangi as Ngati-Rakei of Nga Potiki, and were afterwards known as Ngati-Haka... By inter-marriage they became practically one people with Ngati-Rongo. About three generations ago some of these people were slain by Ngati-Awa at Wai-pokaia, in an uru heuheu or thicket, hence the clan name was changed to Patu-heuheu (thicket slaying) (p. 221). 
Above, Best (1925) claims that Ngāti Haka became one people with Ngāti Rongo through intermarriage. Best (1925) also argues that after an attack by Ngāti Awa, the hapū name was changed to Patuheuheu, meaning 'thicket slaying'. However, in his following account, Ngāti Haka is omitted from the story:

[Ngāti Awa]... attacked some Ngati-Rongo who were living on the Wai-pokaia stream... Ngati-Rongo were surprised and attacked at a place covered with scrub or brushwood, hence, as we have seen, some of them assumed the clan name of Patu-heuheu" (Best, 1925, p. 362).

Best's elucidations of the roots of Patuheuheu are conflicting (Rangiwai, 2018b). This incongruity lines up with the view that some of Best's information was inaccurate (Rangiwai, 2018b). While Best's work continues to influence our understandings of traditional Māori society, his positionality as an amateur ethnographer who deciphered Māori information through a European gaze must be acknowledged (Holman, 2010). Best's assertions of the origins of Patuheuheu are incorrect (Rangiwai, 2018b). Patuheuheu did not come from Ngāti Haka, but is, instead, a branch of Ngāti Rongo (Rangiwai, 2018b). Patuheuheu arose due to a battle between Ngāti Rongo and Ngāti Awa (Rangiwai, 2018b). In this battle, a mokopuna of my ancestor Koura (see Figure 2) was killed; and in memory of this tragedy, a section of Ngāti Rongo renamed themselves, Patuheuheu (Rangiwai, 2018b). 


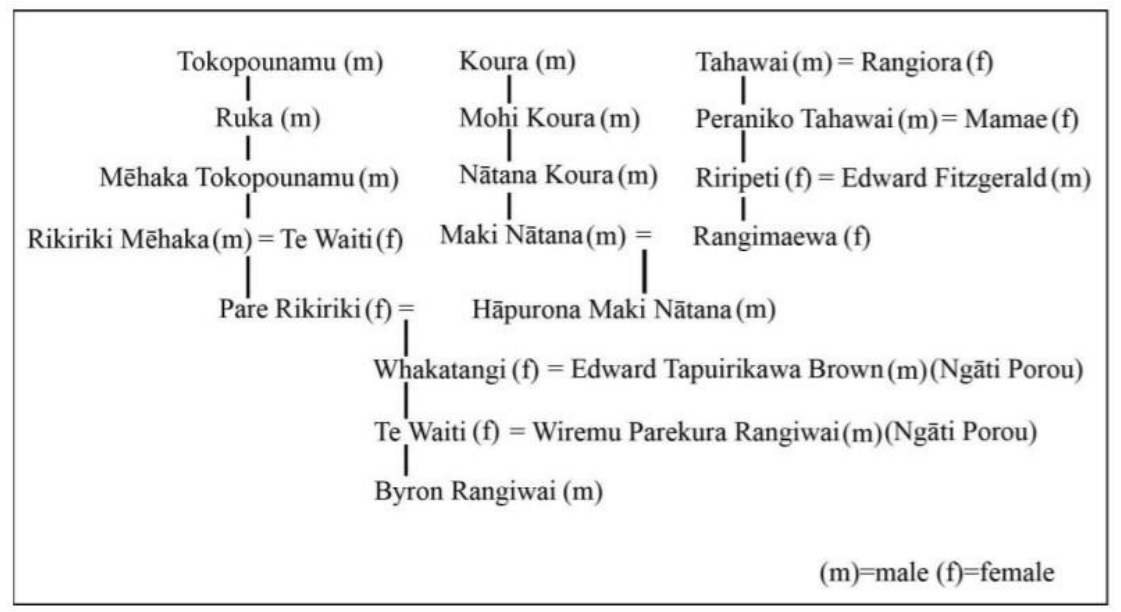

Figure 2. Whakapapa

Koura was a Ngāti Rongo and Patuheuheu chief, who lived at Horomanga in the 1830s and had a close association with Ngāti Manawa (Mead \& Phillis, 1982; Waitangi Tribunal, 2002). Local history upholds that Koura was responsible for asserting and maintaining the mana of Tūhoe in the Te Whaiti, Murupara, Horomanga, Te Houhi and Waiōhau areas (Rangiwai, 2018b). Koura was deeply involved in the political negotiations concerning the tatau pounamu-enduring peace agreement-between Tūhoe and Ngāti Awa that transpired between the early 1830s (Waitangi Tribunal, 2002) and 1835 (Binney, 2009). 


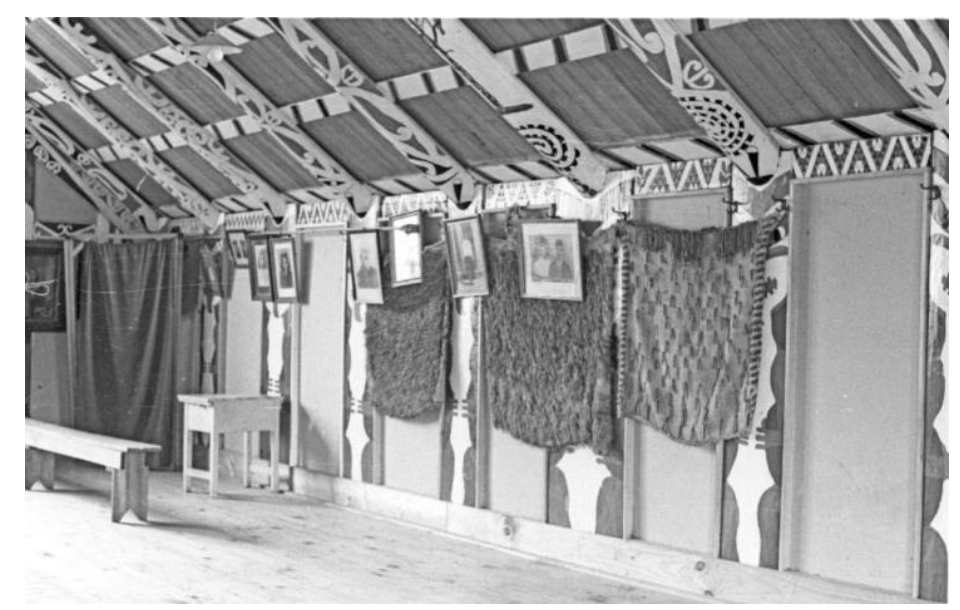

Figure 3. Interior wall (Mead, 1970, PID374248). Note Nātana Koura (see Figure 2) and his wife feature here; their picture hangs over the centre kākahu in this image.

Concerning the tatau pounamu, Mead and Phillis (1982) maintain: "Koura ...is remembered by Ngati Awa and Patuheuheu of Waiohau and Ngati Manawa of Murupara as the principal man on the Tuhoe side" (p. 241). Indeed, Te Kooti's renowned waiata tohutohu, Käore te pō nei mōrikarika noa, reminds Tūhoe and Ngāti Awa of that very agreement: "He rongo ka houhia ki a Ngāti Awa" ("A peace made with Ngāti Awa”) (Binney, 2009, p. 269). This agreement was of enormous importance as it brought 200 years of inter-tribal struggle to an end (Waitangi Tribunal, 2002). The bush symbolised that conflict at Ôhui (Mead \& Phillis, 1982). Mead and Phillis (1982) contend:

...the peace treaty is remembered by the people of the Mataatua region as being between Koura and Hatua ( $p$. 243).

Lesser men could not have cemented the tatau pounamu. ... Koura and Hatua did not fail and as a result their names live on in the memories of the people... 
Koura of Ngati Rongo and Patuheuheu representing the Tuhoe side of the bush at Ohui, and Hatua of Ngati Pahipoto representing the Ngati Awa side of the bush. One is symbolised forever by Tawhiuau which can be seen clearly at Galatea and Murupara and the other is symbolised by Putauaki which dominates the land around Kawerau, Te Teko and Whakatane (p. 245).

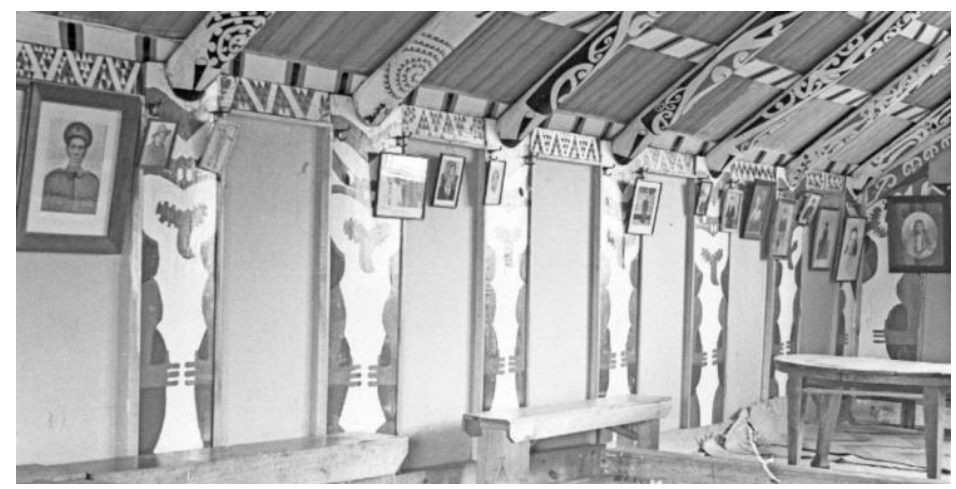

Figure 4. Interior wall (Mead, 1970, PID374250). Note Rangimaewa Fitzgerald's (see Figure 2) oval framed picture hangs at the right edge of this image.

It was here, below the shadow of Tâwhiuau maunga, that Mead (cited in Waitangi Tribunal, 2002) states that Patuheuheu and Ngāti Haka lived under Koura's leadership. For his descendants, Koura is a revered and inspirational figure; and in the Maki Nātana whānau in particular, those who display strength and resilience are said to have 'shoulders like Koura' (Rangiwai, 2018b). 


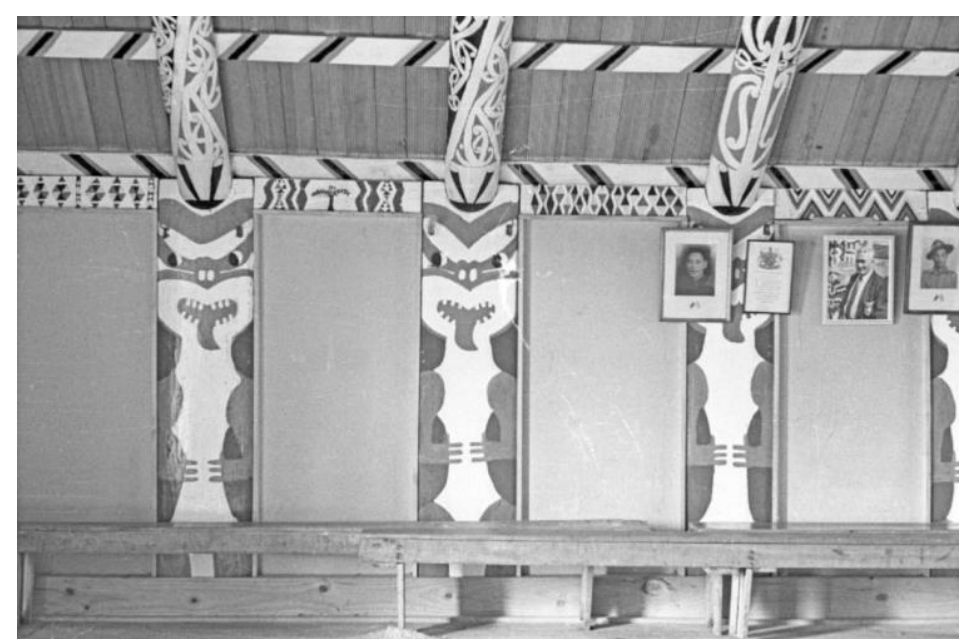

Figure 5. Interior carvings (Mead, 1970, PID374222). Note a photo of Koro Roihi Rikiriki, my great-grandmother Pare's (see Figure 2) brother, hangs closest to the centre.

My great-grandfather, Hāpurona Maki Nātana (Koro Ted), inculcated within my whānau the uncompromising view-based on our direct whakapapa to Koura-that we are authentically and exclusively Patuheuheu.

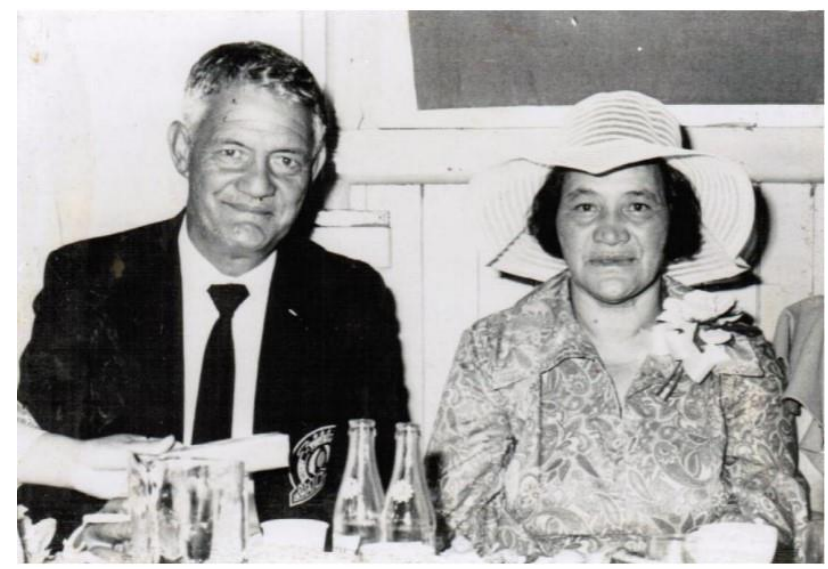

Figure 6. Hāpurona (Ted) Maki Nātana \& Pare Koekoeā Rikiriki (private collection) (see Figure 2). 
The following statement from the Patuheuheu leader, Koro Wiremu McCauley, a cousin to Koro Ted, further crystallises a Patuheuheu perspective:

\begin{abstract}
Sometimes we refer to ourselves as Ngati Patuheuheu and sometimes as Tuhoe. The difference is we are Patuheuheu when our lands, river and mana is at stake. We are Tuhoe when the kawa and tikanga and the larger identity of being one of the many iwi of Tuhoe, are at issue (Rose, 2003, p. 12).
\end{abstract}

\title{
Ringatū
}

For his followers, "Te Kooti was accepted as the Maori messiah, no doubt because of his success in the escape from the Chathams, his powers of faith-healing, and his gift of prophecy" (Barker, 1970, p. 17). The Ringatū faith owes its origins to the revelations that Te Kooti had while imprisoned with hundreds of other Māori political prisoners on the Chatham Islands in the mid-1860s (Binney, 1995). God spoke to Te Kooti and instructed him to teach the people (Binney, 1995). Te Kooti and his followers escaped the Chatham Islands on the ship Rifleman (Binney, 1995). When they landed at Whareongaonga, they raised their right hands in praise and thanks to God for their deliverance; this was the gesture from which the faith received its name, Ringatūthe upraised hand (Binney, 1995). Following their escape, Te Kooti and his followers were ruthlessly pursued by the military (Binney, 1995). Despite the loss of many lives, that pursuit served only to galvanise and strengthen their convictions (Binney, 1995). The Ringatu faith was primarily a religion of resistance and survival, but later became a religion of peace, fashioned by a history of colonisation and land loss and upholding an enduring belief in God (Binney, 1995).

The Ringatu faith was concerned with the issues of the colonised; for its believers, it not only provided hope but offered a framework for analysing the Māori position within the colonial context, while at the same time 
extending to the people a particularly indigenous relationship with God (Binney, 1995; Binney \& Chaplin, 1996). To provide this religio-political scaffold, Te Kooti combined elements of the introduced faith with Māori spirituality to produce a prophetic movement that the people could use to make sense of their situation and reclaim autonomy over their lives (Rangiwai, 2017). Te Kooti's theology, thus, became infused into the whare that he influenced, which emerged as a distinctive style (Rangiwai, 2018b).

\section{Te Kooti's influence on the evolution of whare}

Archaeological evidence shows that early Māori houses were like those found elsewhere in Polynesia (Brown, 2009; Paama-Pengelly, 2010). When groupings of Māori reached Aotearoa from central Polynesia in waves from about 1350, they modified their building techniques to match the colder temperatures and different materials; Māori whare were small, simple and semi-permanent (Brown, 2009; Paama-Pengelly, 2010). However, in the nineteenth century, this was to change.

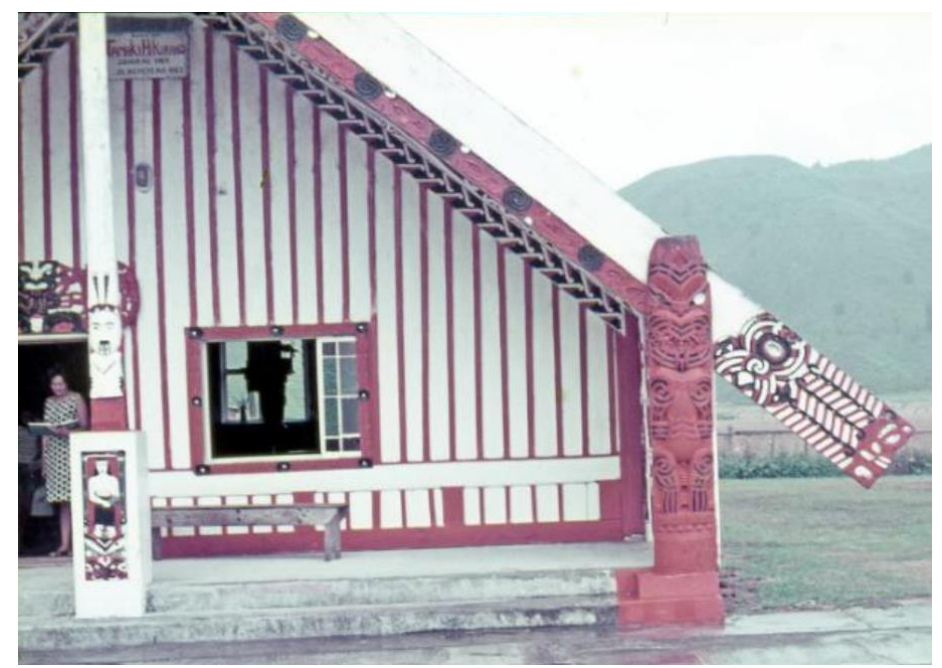

Figure 7. Tama-ki-Hikurangi (Mead, 1970, PID530316 ). 
The New Zealand Wars of $1845-1872$ was a time of immense instability for many North Island Māori. For some Māori leaders, it was an appropriate time, both during and after the hostility, to exhibit the prestige, spirituality and power of the people by constructing very different whare that combined European technologies, techniques and materials; these whare became significantly larger than earlier whare (Brown, 2009). Some Māori rejected the teachings of the missions and created their own faiths, which were mirrored in the biblical concepts and colonial materials upon which these innovative whare were built (Brown, 2009). These whare did not, however, "...represent the integration or assimilation of Māori into the larger Pākehā population, but were a reaction to the conflict, [land] confiscations and loss associated with the New Zealand Wars" (Brown, 2009, p. 58).

Te Kooti directed the religio-political architectural development of the whare during and after the New Zealand Wars to bolster the struggle for justice and spiritual emancipation (Brown, 2009). Williams (1999) contends that Te Kooti "...was directly responsible for influencing the building of great meeting houses..." (p. 80). While Sissons (1998) opines that these whare were "...hybrid structures built during a period of rapid political change" and are "...symbols of political unity in opposition" (pp. 37-38). 


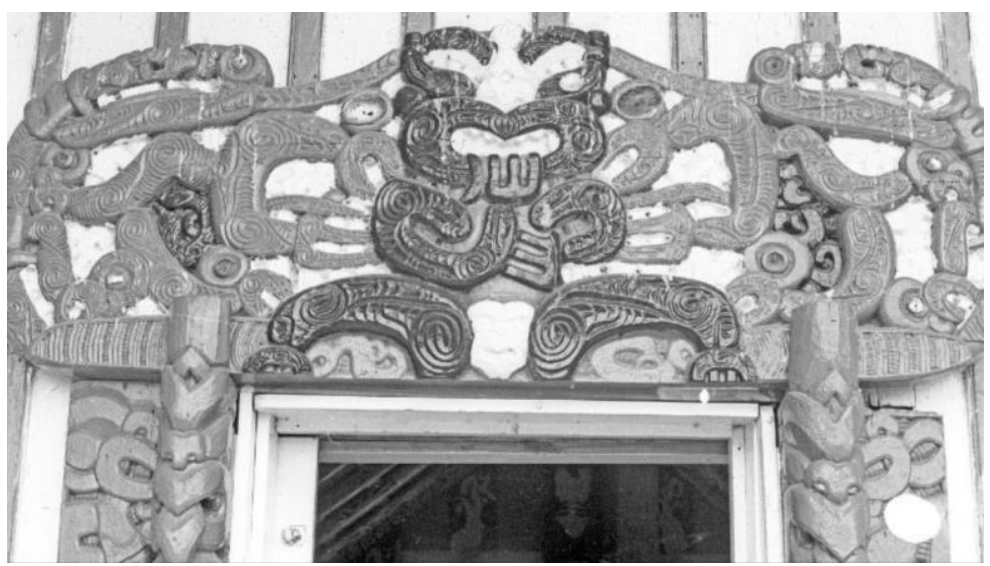

Figure 8. Door lintel (Mead, 1970, PID374214)

Within the Mataatua confederation of tribes-which includes Tūhoe, and by extension Patuheuheu-and under Te Kooti's revelation and leadership, large whare were constructed; these whare were sizeable enough to walk around inside, and some were as large as Christian churches (Brown, 2009; Paama-Pengelly, 2010). 


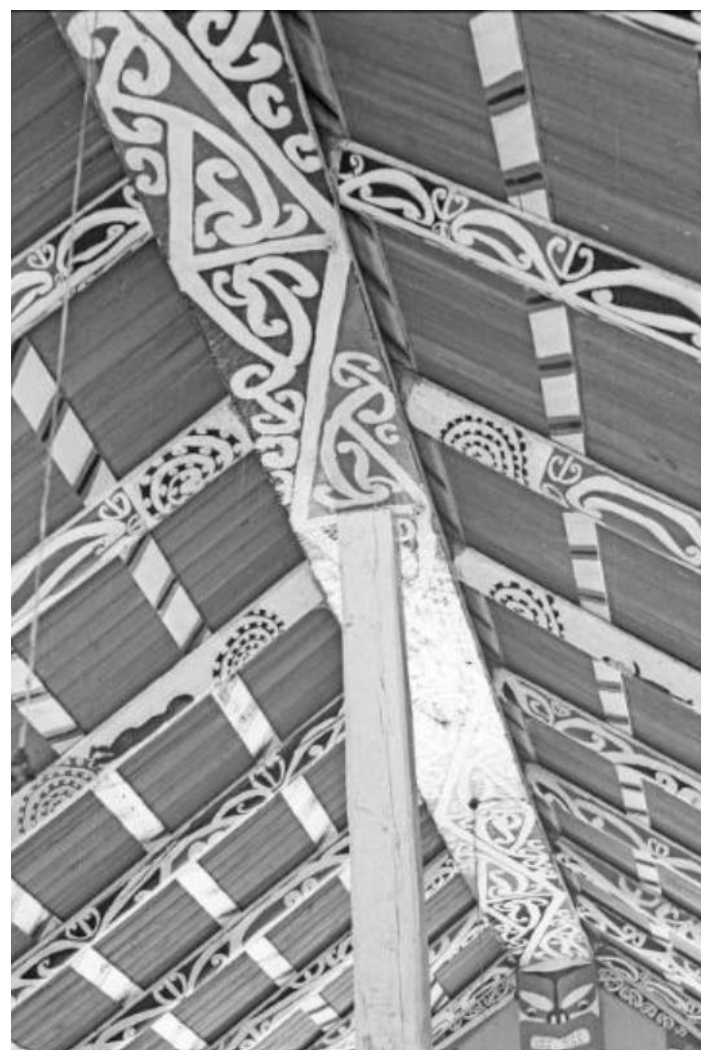

Figure 9. Rafters (Mead, 1970, PID374252)

Davidson (2004) maintains that Te Kooti and his followers relocated worship from churches to the whare. This was important, Davidson (2004) argues, because "In so doing they made a considerable contribution to maintaining and adapting Maori traditions in a way that helped preserve the meeting house as a living focus of Maori identity, history and culture" (p. 47). 


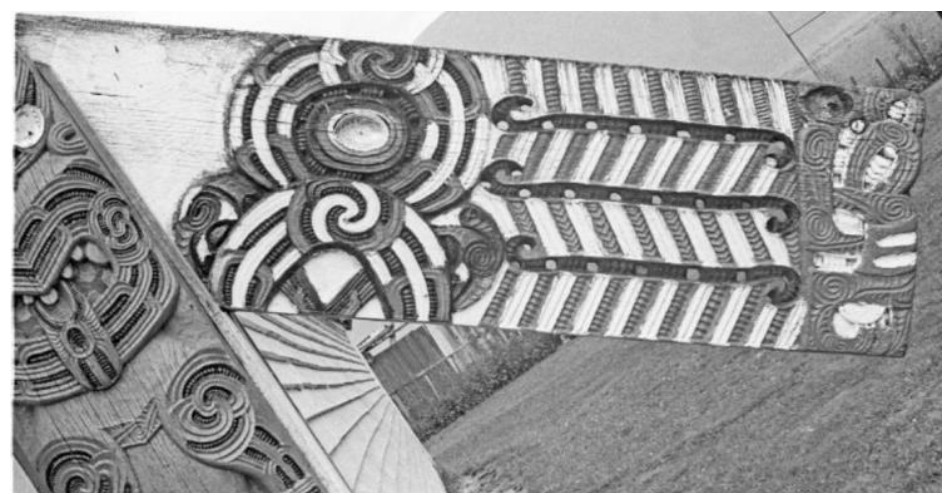

Figure 10. Exterior carvings (Mead, 1970, PID374258)

This new style whare featured polychromatic painted carvings and motifs-some in European artistic styleportraying historical events (Brown, 2009; PaamaPengelly, 2010). The various whare built for Te Kooti communicate an impressive critical awareness that embodies the power of his leadership, his beliefs in justice in the face of land loss and death, as well as spiritual redemption (Rangiwai, 2017).

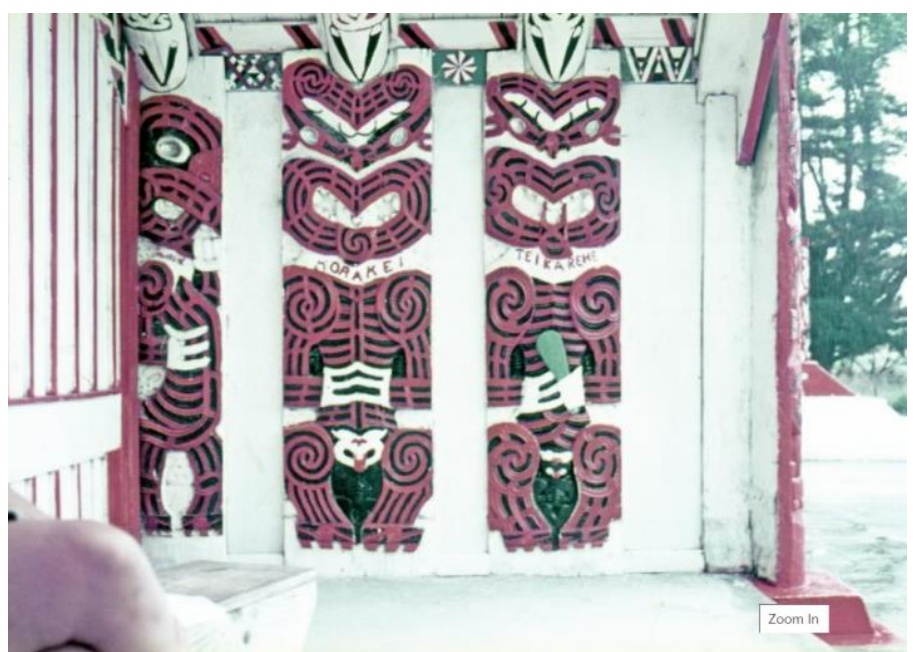

Figure 11. Tama-ki-Hikurangi (Mead, 1970, PID530320) 
As Brown (2009) states: "By combining the functions of religious worship and political debate, Te Kooti and his followers created an architecture that was in sympathy with the needs and outlook of its users" (p. 60).

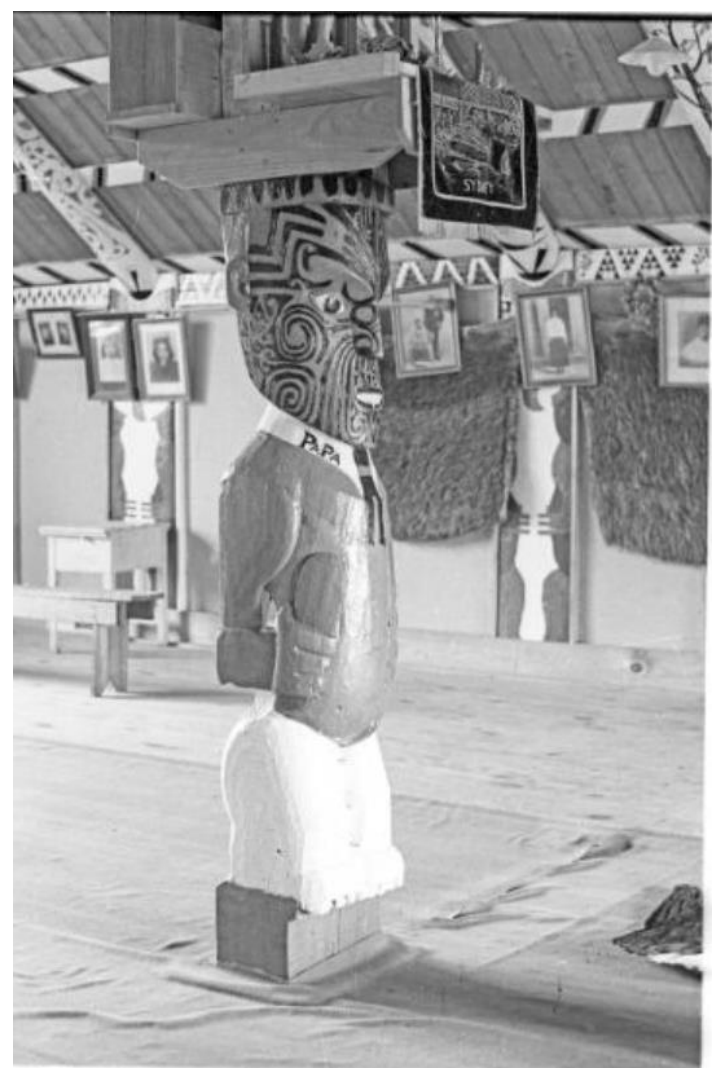

Figure 12. Interior carving (Mead, 1970, PID374216).

Interestingly, Sissons (1998) argues:

The carved Maori meeting house is, then, a traditionalised object with a genealogy in both Foucauldian and Maori senses. Foucauldian, because its genealogy traces links between new forms of 
power/knowledge associated with cultural, commodification and colonial state-formation; Maori, because, in symbolising ancestral connections, it embodies a history of kin-based engagement with these new forms of power (p. 44).

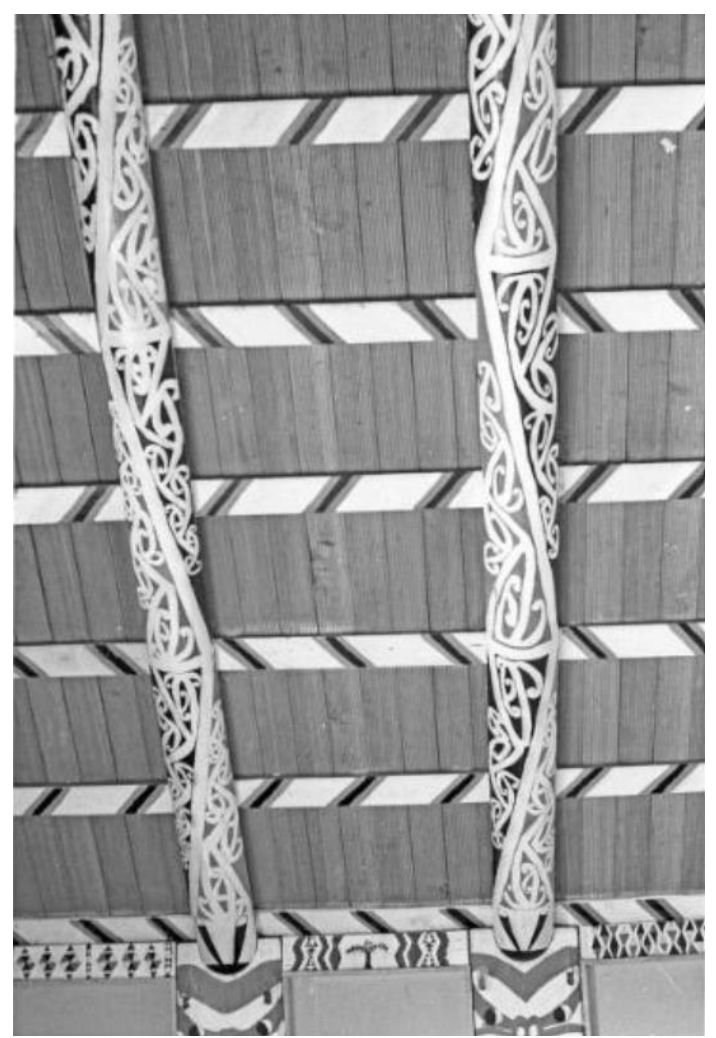

Figure 13. Rafters (Mead, 1970, PID374224)

\section{Tama-ki-Hikurangi: An embodiment of the Ringatu Faith and a symbol of land loss}

In the nineteenth century Patuheuheu, Ngāti Haka, Ngāti Manawa and Ngāti Whare occupied the Te Houhi, Waiōhau and Horomanga areas (Binney, 2009). 
Patuheuheu were followers of Te Kooti, whom the Crown deemed to be a rebel (Binney, 1995). Owing to this association, the government forced the hapu to leave its home in the Rangitaiki Valley, and its members were incarcerated at Te Pūtere, near Matatā, in the eastern Bay of Plenty (Binney, 2009, 2010; Paul, 1995).

In 1872, the Patuheuheu hapū was released and returned to their lands at Te Houhi, which became their main kāinga (Arapere, 2002; Binney, 2009, 2010; Paul, 1995). According to most reports, Tama-ki-Hikurangi, "...a meeting-house built for Te Kooti at Te Houhi (near Galatea) by the Patuheuheu people, a hapu of Tuhoe" (Binney, 1995, caption, plate 2; see also Neich, 1993) was commissioned and built there. Arapere (2002) asserts that the whare was raised in the late 1870s and was transported to Te Houhi. Conversely, Binney (1995, 2010) and Neich (1993), disagree with the idea of a pre-1900s construction, and contend that the whare was built in 1904. Cresswell (1977) and Binney (2001, 2010) insist that Tama-ki-Hikurangi was constructed under the guidance of Tūhoe carver, Te Wharekotua, “...to memorialise their history and their identity linked to Te Kooti" (Binney, 2001, p. 152).

The 1880s, 1890s and early twentieth century was a period of uncertainty for Patuheuheu. During this time colonial maps demarcating the land were redrawn yet again. A devastating act of deceit was on the horizon, and Patuheuheu's home and way of life was again at risk. Harry Burt, a licensed Native Land Court interpreter and supposed friend of the prophet Te Kooti, coordinated treacherous land transactions in the mid-1880s that ultimately led to the displacement of Patuheuheu from their land at Te Houhi in 1907 (Binney, 1995, 2001, 2009, 2010; Boast, 2008).

Harry Burt, or Hare Paati as he was known to the hapū, was not Māori (Auckland Star, 1905 June 8, p. 5), but was a speaker of te reo Māori and worked as an interpreter for the Native Land Court (Binney, 1995, 2001, 2009, 2010; Boast, 2008). Burt used the Native 
Land Court system to acquire the land fraudulently (Binney, 1995, 2001, 2009, 2010; Boast, 2008). This event is known as the Waiōhau Fraud (Boast, 2002). Wharehuia Milroy contends:

\begin{abstract}
Harry Burt was a Pākehā who got involved in some fraudulent dealings with land in and around Te Houhi. He sold the land interests of the Waiōhau Māori for his own gain through fraudulent dealings, where he acquired land interests from people who did not have the authority to sell the land. I don't think those people would have really realised the gravity and danger of engaging with Harry Burt. He stole the land, that's about the best way to describe it; he stole the land from the people at Te Houhi (Rangiwai, 2015, p. 95).
\end{abstract}

Binney (2001) states that Burt belonged to a "...'subculture': a visible group of early settled Pakeha men who lived with Maori women" (p. 162) and spoke the native language. Harry Burt was a trickster who hid behind a cloak of colonial hybridity (Binney, 1995, 2001, 2010). Burt "claimed friendship and more-kinship-with Maori... He was a manipulator, who created a mood and experience of confidence and trust. He was a swindler who outmanoeuvred a prophet" (Binney, 2001, p. 148). The block of land on which Te Houhi was located was known in the Native Land Court in 1878 as Waiohau 1 (Arapere, 2002; Binney, 2001, 2009, 2010; Paul, 1995). In January 1886, a committee of twelve Tūhoe men, joined by Te Kooti, met with Burt to negotiate; they asked Burt to accept 1,000 acres of land to satisfy his land needs (Binney, 2001, 2009, 2010). However, Waiohau 1 was illegally brought before the Court for partition by Hare Rauparaha, one of Burt's pseudonyms (Waiariki Māori Land Court, 1886, February 16). By using the name Hare Rauparaha, Burt exploited his position as an interpreter in the Native Land Court and fabricated a new identity by misappropriating whakapapa and mana from the name of the famous Ngāti Toa chief, Te Rauparaha (Binney, 2001, 2009, 2010; "Waiohau 1B inquiry", 1889, 
October 31). Burt's partition was to establish half of the block, 7,000 acres, as Waiohau $1 \mathrm{~B}$ in the name of two Ngāti Manawa owners, Pani Te Hura, also known as Peraniko Ahuriri and Hira Te Mumuhu (Binney 2001, 2009, 2010; Stokes et al., 1986). These men, manipulated by Burt, immediately sold the newly established Waiohau $1 \mathrm{~B}$ in the Court foyer, witnessed by Judge H. T. Clarke and Harry Burt (Binney, 2001, 2009, 2010).

Burt's dishonest acts were examined by a judicial inquiry in 1889, established through a Parliamentary recommendation in response to a petition from Mēhaka Tokopounamu and 86 others (Binney, 2001, 2009, 2010; "Native Affairs Committee response to the petition of Mehaka Tokopounamu and 86 others (Petition 257)", 1889, August 21; Paul, 1995). The petition claimed that Harry Burt had dishonestly obtained Waiohau 1B ownership by compelling people to sell their shares to him (Binney, 2001, 2009, 2010; Paul, 1995). Te Kooti renamed Te Houhi, Te Umutaoroa, and told Mēhaka and the other petitioners that Burt's money would be like a pit of rotting potatoes and that he would never gain possession of the land ("Burt, signed statement", 1887, December 10; Burt, 1889; "Statement made by Burt on 29 October 1889", 1889, October 29). However, this particular prediction was not to come true. Burt's actions included using the signatures of minors, acquiring shares from those who did not own them, purchasing without witnesses, purchasing the shares of deceased persons, getting people drunk and then getting them to sign over their shares, and finally by giving guns and gun powder (Paul, 1995).

The judicial inquiry found that the Native Land Court's partition order was based on proof given by Māori whom Burt manipulated (Binney, 2001, 2010; "Petition of Mehaka Tokopounamu and 86 others (No. 257)", 1889; Paul, 1995). The inquiry was then referred to Judge Wilson, who in 1889, after a lengthy investigation, found that "Burt behaved fairly toward the natives in the matter of this purchase until they turned against him and placed 
themselves under the guidance of Te Kooti” (Paul, 1995, p. 29).

Patuheuheu were disadvantaged and impoverished by the court disputes relating to Te Houhi. However, the courts recognised that the people of Te Houhi had been brutally wronged, but were unwilling to help (Binney, 2001). The judge stated:

I regret the hardship to the defendants. That they have suffered a grievous wrong is, in my opinion, plain. It is doubly hard that this wrong should have resulted from a miscarriage, which certainly ought to have been avoided, in the very Court which was specially charged with the duty of protecting them in such matters. The plaintiff is, of course, blameless in the matter (cited in Binney, 2001, p. 151).

The land on which Te Houhi was located ultimately came into James Grant's ownership, in part because of his own manipulations (Binney, 2001, 2010). The people had been advised in 1890 by their lawyer, Howorth, that maintaining peaceful and continued occupation of their land would be enough to ensure ownership; the people would only leave if forced (Binney, 2009). However, when Grant took official ownership of the land in February 1907, he made it difficult for the people to stay by destroying their cultivations; he eventually evicted the people, assisted by the police, in the winter of 1907 (Binney, 2001, 2009, 2010; Boast, 2002; Wylie, 1908, cited in Wouden, 1980). Some local accounts insist that Patuheuheu were evicted at gunpoint. Boast (2002) states:

The mean-spirited and vindictive James Grant, a local landholder who was apparently driving the entire process, ensured that the eviction process was as complete and demeaning as possible, even preventing them from taking their school house and wharenui from the land (p. 156). 
Patuheuheu were forced to leave behind their whare, a church and schoolhouse, and the sacred bones of their dead (Binney, 2001, 2009, 2010). Some reports argue that the government later purchased the whare from Grant, who used the whare as a haybarn, for $£ 140$ in 1908 (Binney, 2001, 2009, 2010; Boast, 2002; Paul, 1995). Notwithstanding the various accounts, it is clear that the people removed and relocated the whare piece by piece, refusing all assistance, except for a $\$ 40$ grant from the government to purchase food for those without (Binney, 2001, 2009, 2010). According to Binney (2001, 2009, 2010), the whare would have been moved by wagon. Nevertheless, local oral accounts claim that the whare was transported in parts via the Rangitaiki River. Tama-ki-Hikurangi was re-opened at Waiohau on 28 July 1909 (Binney, 2001, 2009, 2010; Paul, 1995).

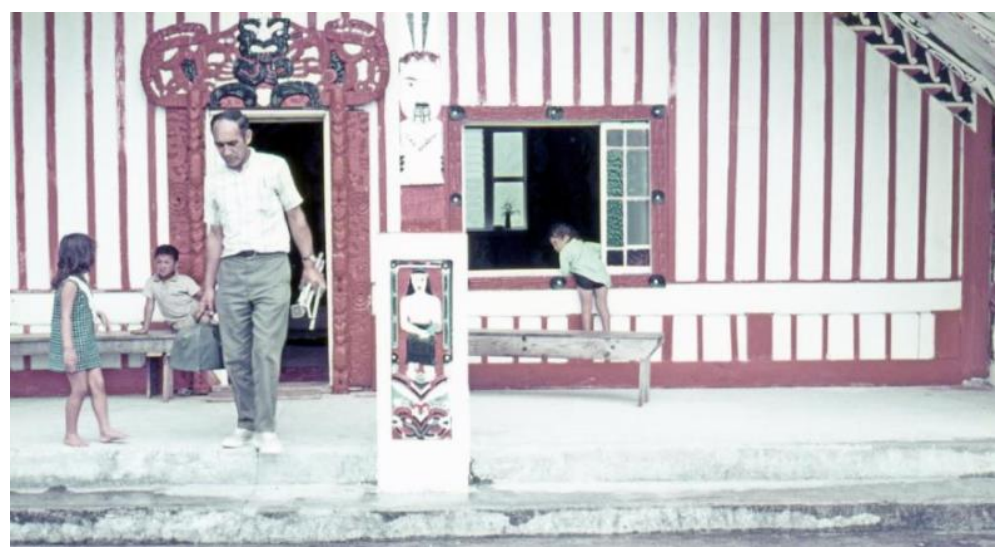

Figure 14. Tama-ki-Hikurangi (Mead, 1970, PID530314). Note Sir Hirini Moko Mead is featured in this image.

\section{Conclusion}

This paper has presented a history of Tama-ki-Hikurangi that is clearly and undeniably connected to the theology of Te Kooti. Tama-ki-Hikurangi was built for Te Kooti at Te Houhi and was relocated to Waiōhau due to land loss. 
Te Kooti's faith resides among the remnants of his followers at Waiohau. Among those who continue to practise the faith at Waiōhau, it is hoped that one day, the rest of the flock might return fully to the practises and beliefs of Te Kooti. 


\section{References}

Arapere, B. (2002). A history of the Waiohau blocks: A report commissioned by the Waitangi Tribunal (Wai 894 \#A26). Waitangi Tribunal.

Barker, D. (1970). Maori sectarianism: Ringatu and Ratana: Towards a theology of culture. The Presbytery of South Auckland.

Best, E. (1925). Tuhoe: Children of the mist. Reed.

Binney, J. (1995). Redemption songs: A life of Te Kooti Arikirangi Te Turuki. University Press \& Bridget Williams Books.

Binney, J. (2001). Te Umutaoroa: The earth oven of long cooking. In A. Sharp \& P. McHugh (Eds.), Histories, power and loss: Uses of the past - a New Zealand commentary (pp. 146-64). Bridget Williams Books.

Binney, J. (2009). Encircled lands: Te Urewera, 18201921. Bridget Williams Books.

Binney, J. (2010). Stories without end: Essays 19752010. Bridget Williams Books.

Binney, J. \& Chaplin, G. (1996). Ngā mōrehu - the survivors: The life histories of eight Maori women. Oxford University Press \& Bridget Williams Books.

Boast, R. P. (2002). The Crown and Te Urewera in the 20th century - a study of government policy. Waitangi Tribunal.

Boast, R. (2008). Buying the land, selling the land. Victoria University Press.

Brown, D. (2009). Māori architecture: From fale to wharenui and beyond. Penguin.

"Burt, signed statement" (1887, December 10). Maori Affairs (MS 1/1920/218/1). Archives New Zealand.

Cresswell, J. C. M. (1977). Maori meeting houses of the North Island. PCS Publications.

Davidson, A. K. (2004). Christianity in Aotearoa: A history of church and society in New Zealand. The New Zealand Education for Ministry Board.

Holman, J. F. (2010). Best of both worlds: The story of Elsdon Best and Tutakangahau. Penguin. 
"Native Affairs Committee response to the petition of Mehaka Tokopounamu and 86 others (Petition 257)" (1889, August 21). Maori Affairs (MS $1 / 1920 / 218 / 1)$. Archives New Zealand.

Mead, H. M. \& Phillis, O. E. (1982). The abundant earth Te one matua: The centennial of Ruataupare at Kokohinau marae. Te Komiti Maori o Kokohinau.

Mead, S. M. (1970). Door lintel. Anthropology Photographic Archive, Department of Anthropology, University of Auckland (PID374214).

Mead, S. M. (1970). Exterior carvings. Anthropology Photographic Archive, Department of Anthropology, University of Auckland (PID374258).

Mead, S. M. (1970). Interior carving. Anthropology Photographic Archive, Department of Anthropology, University of Auckland (PID374216).

Mead, S. M. (1970). Interior carvings. Anthropology Photographic Archive, Department of Anthropology, University of Auckland (PID374222).

Mead, S. M. (1970). Interior wall. Anthropology Photographic Archive, Department of Anthropology, University of Auckland (PID374248).

Mead, S. M. (1970). Interior wall. Anthropology Photographic Archive, Department of Anthropology, University of Auckland (PID374250).

Mead, S. M. (1970). Rafters. Anthropology Photographic Archive, Department of Anthropology, University of Auckland (PID374252).

Mead, S. M. (1970). Rafters. Anthropology Photographic Archive, Department of Anthropology, University of Auckland (PID374224).

Mead, S. M. (1970). Tama-ki-Hikurangi. Anthropology Photographic Archive, Department of Anthropology, University of Auckland (PID530310).

Mead, S. M. (1970). Tama-ki-Hikurangi. Anthropology Photographic Archive, Department of Anthropology, University of Auckland (PID530314). 
Mead, S. M. (1970). Tama-ki-Hikurangi. Anthropology Photographic Archive, Department of Anthropology, University of Auckland (PID530316).

Mead, S. M. (1970). Tama-ki-Hikurangi. Anthropology Photographic Archive, Department of Anthropology, University of Auckland (PID530320).

Neich, R. (1993). Painted histories: Early Maori figurative painting. Auckland University Press.

Paama-Pengelly, J. (2010). Māori art and design: Weaving, painting, carving and architecture. New Holland.

"Petition of Mehaka Tokopounamu and 86 others (No. 257)" (1889). Native Affairs Committee. Victoria University of Wellington. http://nzetc.victoria.ac.nz/tm/scholarly/teiNat1889Repo-t1-g1-g1-t14-g1-t1.html

"Petition of Mehaka Tokopounamu and 63 others, of Galatea, Bay of Plenty District (No. 388)" (1906). Victoria University of Wellington. http://nzetc.victoria.ac.nz/tm/scholarly/teiNat1906Repo-t1-g1-t10.html

Rangiwai, B. (2015). Ko au ko Te Umutaoroa, ko Te Umutaoroa ko au: Toward a Patuheuheu hapū development model [Doctoral thesis]. Auckland University of Technology. https://openrepository.aut.ac.nz/handle/10292/ $\underline{8851}$

Rangiwai, B. (2017). The critical theory of Te Kooti Arikirangi Te Turuki. Te Kaharoa: The eJournal on Indigenous Pacific Issues, 10(1), 194-240. https://www.tekaharoa.com/index.php/tekaharo a/article/view/165

Rangiwai, B. (2018a). Hereditary entanglement-the significance of whakapapa and genealogical locatedness in Māori research: A researcher's personal experience. Te Kaharoa: The eJournal on Indigenous Pacific Issues, 11(1), 139-170. https://www.tekaharoa.com/index.php/tekaharo a/article/view/177 
Rangiwai, B. (2018b). Te Kooti's slow-cooking earth oven prophecy: A Patuheuheu account and a new transformative leadership theory. Te Kaharoa: The eJournal on Indigenous Pacific Issues, 11(1), ii-115. https://www.tekaharoa.com/index.php/tekaharo a/article/view $/ 240$

Rose, K. (2003). A people dispossessed: Ngati Haka Patuheuheu and the Crown, 1864-1960. Crown Forest Rental Trust.

Sissons, J. (1998). The traditionalisation of the Maori meeting house. Oceania, 69(1), 36-46.

"Statement made by Burt on 29 October 1889" (1889, October 29). Maori Affairs (MS 1/1920/218/2, pp. 57-58). Archives New Zealand.

Stokes, E., Milroy, W. J., \& Melbourne, H. (1986). People, land and forests of Te Urewera. University of Waikato.

Waiariki Māori Land Court (1886, February 16). Hare Rauparaha. Closed file Waiohau 304, Rotorua, New Zealand.

"Waiohau 1B inquiry" (1889, October 31). Maori Affairs (MS 1/1920/218/1, p. 86). Archives New Zealand.

Waitangi Tribunal (2002). The Ngāti Awa settlement crossclaims report. Author.

Williams, H. (1999). Te Kooti - te tangata. In W. Curnow \& L. Davis (Eds.), Te Tangi a te Matuhi (pp. 75-82). Jack Books.

Wouden, A. (1980). Te Houhi, the land, the people and the school. Historical review: Journal of the Whakatane and District Historical Society, 28(1), 216. 